\title{
Sistem Penyadapan Karet (Hevea brasiliensis Muell. Arg.) di Tulung Gelam Estate, Sumatera Selatan
}

Tapping Sistem of Rubber ( $\underline{\text { Hevea }} \underline{\text { brasiliensis }}$ Muell. Arg.) at Tulung Gelam Estate, South Sumatera

\author{
Robianto, Supijatno* \\ ${ }^{1}$ Departemen Agronomi dan Hortikultura, Fakultas Pertanian, Institut Pertanian Bogor \\ (Bogor Agrultural University), Jl. Meranti, Kampus IPB Darmaga, Bogor 16680, Indonesia \\ Telp.\&Faks.62-251-8629353 e-mail agronipb@indo.net.id \\ *Penulis untuk korespondensi: supijatno@yahoo.com
}

Disetujui 17 Mei 2017/Published online 22 Mei 2017

\begin{abstract}
The research was conducted in order to increase the knowledge, skills, field experience, and aims to analyze tapping sistem of rubber. The activity was conducted at Tulung Gelam Estate, PT PP London Sumatera Indonesia, Tbk. South Sumatera from February to June 2013. Tapping is the mayor activity in rubber production system. The average percentage of trees that can be tapped at Tulung Gelam Estate is 87.4\%. Brown blast disease on 2004 planted year were higher than the 2006 planted year. Bark consumption at Tulung Gelam Estate was less than bark consumption company standards but still be tolerated. Avarage tapping depth was $1.62 \mathrm{~mm}$ that still under company recomendation $(1-1.5 \mathrm{~mm})$. The usage of stimulant were higher than the recomended doses company. Factors of education, age and exprience of tapper did not affect the production of latex produced by tapper.
\end{abstract}

Key words : bark consumption, rubber, tapping system, tulung gelam estate

\begin{abstract}
Penelitian dilaksanakan untuk menigkatkan pengetahuan, keterampilan, dan pengalaman lapangan, serta bertujuan menganalisis sistem penyadapan karet. Kegiatan ini dilaksanakan di Kebun Tulung Gelam Estate, Sumatera Selatan pada bulan Februari sampai Juni 2013. Penyadapan merupakan kegiatan utama dalam sistem produksi karet. Rata-rata persentase pohon yang dapat disadap di Tulung Gelam Estate adalah 87.4\%. Penyakit brown blast (kering alur sadap) pada tanaman menghasilkan (TM) 2004 lebih tinggi dibandingkan pada tanaman menghasilkan (TM) 2006. Konsumsi kulit di Perkebunan Tulung Gelam Estate sedikit melebihi standar perusahaan, namun masih dapat ditolerir. Rata-rata kedalaman sadapan adalah $1.62 \mathrm{~mm}$, masih dibawah rekomendasi perusahaan yaitu 1-1.5 mm. Penggunaan stimulan lebih tinggi dari dosis anjuran. Faktor pendidikan, usia, dan pengalaman tidak mempengaruhi terhadap produksi lateks yang dihasilkan oleh penyadap.
\end{abstract}

Kata kunci : karet, konsumsi kulit, sistem penyadapan, tulung gelam estate 


\section{PENDAHULUAN}

Tanaman karet (Hevea brasiliensis) merupakan salah satu komoditi perkebunan yang mempunyai peran cukup penting dalam kegiatan perekonomian Indonesia dan juga salah satu komoditi ekspor Indonesia yang memiliki peranan sebagai sumber penghasil devisa negara di luar minyak dan gas. Permintaan karet dunia pun terus meningkat dari tahun ke tahun, sehingga Indonesia mempunyai peluang paling besar untuk memanfaatkan potensi pasar tersebut (Damanik et al. 2010). Data BPS (2012) menyebutkan bahwa pada tahun 2011 volume ekspor karet alam Indonesia mencapai 2555739 ton dengan total nilai ekspor sebesar US\$11.76 milyar.

Perkembangan luas lahan dan produksi karet Indonesia terus mengalami peningkatan. Pada tahun 2010 lahan perkebunan karet Indonesia seluas 3.45 juta hektar, kemudian mengalami peningkatan pada tahun 2011 menjadi 3.46 juta hektar atau meningkat $0.31 \%$ dari tahun 2010, sedangkan untuk tahun 2012 diperkirakan luas areal perkebunan karet Indonesia masih akan meningkat sebesar $0.16 \%$, sedangkan produksi karet Indonesia pada tahun 2010 mengalami peningkatan $12.07 \%$ menjadi sebesar 2.73 juta ton dan terus mengalami peningkatan pada tahun 2011 sebesar $12.93 \%$ atau menjadi 3.09 juta ton.

Permasalahan utama perkaretan Indonesia saat ini adalah masih rendahnya tingkat produktivitas karet rata-rata indonesia jika dibandingkan dengan negara pesaing utama, seperti Malaysia dan Thailand. Pada awal dekade 1990-an produktivitas karet rata-rata Indonesia hanya berkisar $500 \mathrm{~kg} / \mathrm{ha} / \mathrm{tahun}$, masih dibawah produktivitas karet Malaysia dengan 1000 $\mathrm{kg} / \mathrm{ha} / \mathrm{tahun}$ dan Thailand $750 \mathrm{~kg} / \mathrm{ha} / \mathrm{tahun}$ (Setiawan dan Andoko 2008), sedangkan pada tahun 2010 tingkat produktivitas karet Indonesia sebesar $986 \mathrm{~kg} / \mathrm{ha} /$ tahun, Malaysia 1100 $\mathrm{kg} / \mathrm{ha} /$ tahun, dan Thailand $1600 \mathrm{~kg} / \mathrm{ha} / \mathrm{tahun}$ (Boerhendhy dan Amypalupy 2010).

Salah satu faktor penting yang menyebabkan rendahnya produktivitas karet Indonesia adalah masih rendahnya mutu penyadapan, terutama penerapan teknik penyadapan yang tidak sesuai dengan aturanaturan tertentu dan prinsip-prinsip yang benar, seperti kedalaman sadapan yang tidak sesuai anjuran, terlalu dangkal dan terlalu dalam hingga melukai kambium, konsumsi kulit sadapan yang terlalu boros (lebih dari $2 \mathrm{~mm}$ ), dan waktu penyadapan yang terlalu siang, serta efek penggunaan stimulansia berlebihan yang disertai intensitas penyadapan yang terlalu tinggi sehingga memicu terjadi penyakit kekeringan alur sadap (KAS) pada tanaman karet. Teknik penyadapan menjadi penting karena sangat berkaitan dengan umur ekonomis tanaman, produktivitas, produksi dan kualitas lateks yang dihasilkan (Siregar dan Suhendry 2013)

Menurut Damanik et al. (2010) dalam pelaksanaan penyadapan ada hal-hal yang harus diperhatikan adalah waktu penyadapan harus dilakukan sepagi mungkin (05.00 WIB-08.00 WIB) saat tekanan turgor masih tinggi, kedalaman irisan sadapan yang sesuai dengan anjuran, yakni 1-1.5 mm dari lapisan kambium, konsumsi kulit sadapan 1.5-2 mm, mempertahankan sudut sadap $35^{\circ}-40^{\circ}$ terhadap bidang horizontal, dan penggunaaan stimulansia yang sesuai dengan dosis anjuran.

Penyadapan pada tanaman karet merupakan tindakan panen yang berkelanjutan hingga puluhan tahun. Karena itu, penerapan sistem sadap memerlukan suatu mekanisme panen dimana faktor frekuensi, panjang alur sadap, arah sadapan, kedalaman sadap, aplikasi stimulan atau perubahan-perubahannya diformulasikan sehingga dapat diterapkan secermat mungkin di lapangan serta dilakukan pengawasan sadapan yang bertujuan menghindari terjadinya kesalahan penyadapan.

Secara umum tujuan penelitian adalah untuk menambah wawasan dan pengetahuan serta meningkatkan keterampilan dan pengalaman, baik yang menyangkut aspek teknis dan manajerial di lapangan. Tujuan penelitian secara khusus adalah mengkaji aspek khusus yaitu mempelajari dan menganalisis Sistem Penyadapan Karet di Tulung Gelam Estate, Sumatera Selatan.

\section{METODE PENELITIAN}

Kegiatan penelitian ini dilaksanakan di Tulung Gelam Estate, Sumatera Selatan. Kegiatan penelitian dilaksanakan selama 4 bulan dimulai bulan Februari 2013 sampai dengan Juni 2013.

Kegiatan penelitian ini dilaksanakan dengan mengikuti kegiatan teknis dan kegiatan manajerial. Kegiatan teknis dilakukan untuk mendapatkan keterampilan teknis. Kegiatan yang dilakukan adalah menjadi Karyawan Harian Lepas (KHL) selama satu bulan, Pendamping Mandor selama satu bulan, dan Pendamping Asisten Divis dua bulan dengan mengikuti kegiatan sesuai dengan yang dilaksanakan di lapang. Kegiatankegiatan teknis yang dilakukan antara lain pembibitan, pemupukan, pengendalian gulma, penyadapan, dan aplikasi stimulansia. Kegiatan manajerial untuk memperoleh keterampilan 
manajerial dilaksanakan dengan bekerja sesuai dengan tingkatan manajerial yang ada, diantaranya menjadi Pendamping Mandor dan Krani Divisi serta Pendamping Asisten Divisi.

Metode pengumpulan data yang digunakan pada saat penelitian adalah metode langsung dan metode tidak langsung. Metode langsung dilakukan dengan mengumpulkan data primer dengan cara wawancara, diskusi dan pengamatan langsung di lapangan, antara lain persentase pohon yang dapat disadap, persentase pohon yang terserang kering alur sadap (KAS), kondisi kulit sadapan, dan penggunaan stimulansia serta tenaga kerja sadap. Metode tidak langsung dilakukan dengan studi literatur dan pengumpulan data sekunder, yaitu data-data kebun seperti keadaan umum perusahaan dan kebun, keadaan iklim, luas areal dan populasi tanaman TBM dan TM, keadaan tanaman (klon dan umur tanaman) dan struktur organisasi dan ketenagakerjaan, serta data pola produksi enam tahun terakhir.

Dalam kegiatan penelitian terdapat beberapa parameter khusus yang diamati, yaitu mengenai aspek khusus Sistem Penyadapan Tanaman Karet, seperti : persentase pohon yang dapat disadap, persentase pohon yang terserang kering alur sadap (KAS), kondisi kulit sadapan, penggunaan stimulansia, dan tenaga kerja sadap terhadap produksi lateks. Pengumpulan data dilakukan dengan pengamatan dan pengukuran langsung di lapangan serta melakukan wawancara dengan para penyadap dan mandor.

Pengamatan ini dilakukan dengan menghitung jumlah pohon yang dapat disadap per hanca sadap. Data diperoleh dengan melakukan sensus langsung dan wawancara terhadap mandor dan penyadap. Pengamatan dilakukan dengan mengikuti 8 orang tenaga penyadap pada satu kemandoran dengan sistem sadap $1 / 2$ s $\quad d / 3$, sehingga diamati tiga hanca sadap pada masingmasing tenaga penyadap

Pengamatan dilakukan dengan menghitung jumlah pohon yang terserang kering alur sadap per hanca sadap. Data diperoleh dengan sensus langsung terhadap gejala kering alur sadap (KAS) dan wawancara terhadap mandor dan penyadap. Pengamatan dilakukan dengan mengikuti 8 orang tenaga penyadap dengan setiap penyadap diamati sebanyak tiga hanca sadap (sistem sadap $1 / 2 \mathrm{~s} \mathrm{~d} / 3$ ).

Pengamatan dilakukan dengan mengikuti 4 orang tenaga penyadap pada satu kemandoran dengan frekuensi penyadapan tiga hari sekali (d/3) dengan masing-masing tiga hanca sadap setiap penyadap. Setiap hanca diamati sebanyak 10 tanaman contoh. Pengamatan ini bertujuan untuk melihat dan membandingkan kondisi kulit sadapan di lapangan dengan standar yang telah ditetapkan perusahaan. Adapun parameter kondisi sadapan yang diamati adalah : Panjang alur sadap, tinggi alur sadap, lingkar batang, konsumsi kulit sadapan, dan kedalaman sadapan.

Pengamatan tentang penggunaan stimulan dilakukan dengan melihat proses pengenceran, frekuensi pemberian, dosis stimulan per tanaman, merk dagang, bahan aktif, dan cara aplikasinya dengan mengamati secara langsung pekerja di lapangan dan wawancara dengan mandor di lapangan. Pengamatan ini bertujuan untuk melihat dan membandingkan penggunaan stimulansia di lapangan dengan standar yang telah ditetapkan perusahaan.

Pengamatan dilakukan untuk memperoleh data produksi di lapangan berdasarkan tenaga kerja dilihat dari usia, pendidikan, dan pengalaman penyadap. Data diperoleh melalui wawancara langsung setiap penyadap dan mandor, serta data dari buku daily crop krani timbang pada satu kemandoran dengan tiga rotasi sadap pada masing-masing hanca.

Data yang diperoleh dianalisis menggunakan analisis deskriptif dengan melihat nilai rata-rata dari data yang didapat. Nilai ratarata yang didapat kemudian dibandingkan dengan standar yang telah ditetapkan oleh perusahaan. Selain itu juga dilakukan uji $t$-student pada taraf 5\%, hasil t-hitung kemudian dibandingkan dengan t-tabel (Walpole 1992). Apabila t-hitung berada dalam wilayah kritik maka hasil pengamatan berbeda nyata. Sebaliknya, jika thitung berada di luar wilayah kritik maka hasil pengamatan tidak berbeda nyata.

\section{HASIL DAN PEMBAHASAN}

\section{Kondisi Umum}

Perkebunan Karet TGE terletak di Desa Talang Jaya, Kecamatan Sungai Menang, Kabupaten Ogan Komering Ilir, Propinsi Sumatera Selatan yang terletak antara $03^{\circ} 30^{\prime}-$ $03^{\circ} 33^{\prime}$ LS dan $105^{\circ} 17^{\prime}-105^{\circ} 35^{\prime}$ BT. Perkebunan Karet TGE berbatasan dengan Kecamatan Cengal dan Desa Cengal di sebelah Utara, sebelah selatan berbatasan dengan Kecamatan Sungai Menang, sebelah timur berbatasan dengan Desa Cengal dan Kecamatan Sungai Menang, dan di sebelah barat berbatasan dengan Desa Sedyomulyo dan Kayu Labu. Perkebunan Karet TGE berada pada ketinggian \pm 100 meter di atas permukaan laut (dpl) dengan kelerengan lahan datar dan sedikit bergelombang dengan kemiringan $0-8 \%$. 
Kondisi iklim di Perkebunan TGE menurut klasifikasi Schmidth dan Ferguson memiliki tipe iklim B dengan suhu rata-rata $30^{\circ} \mathrm{C}$ dan kelembaban di atas $80 \%$. Rata-rata curah hujan tahunan $2172.4 \mathrm{~mm}$ dengan rata-rata 8.7 bulan basah dan 2.6 bulan kering, sedangkan ratarata jumlah hujan tahunan adalah 119 . Jenis tanah di Perkebunan Karet TGE merupakan tanah aluvial dengan tekstur liat berpasir sampai lempung liat berdebu. Drainase baik dan $\mathrm{pH}$ tanah berkisar antara 5- 6.5.

Perkebunan Karet TGE memiliki luas lahan mencapai 2777.67 ha yang dibagi menjadi empat divisi, yaitu Divisi Tulung Gelam Satu (TGS), Divisi Tulung Gelam Dua (TGD), Divisi
Tulung Gelam Tiga (TGT), dan Divisi Tulung Gelam Empat (TGE). Luas areal tanaman menghasilkan (TM) sebesar 1397.68 ha dan luas areal tanaman belum menghasilkan (TBM) 941.15 ha.

Perkebunan TGE mulai melakukan pembukaan lahan dan penanaman pada tahun 1995 dan mulai berproduksi pada tahun 2002 dengan tahun tanam terdiri dari : 1995, 1996, 1997, 1998, 2001, 2004, 2006, 2007, 2008, 2009, 2010, 2011, dan 2012. Jenis klon yang ditanam di TGE antara lain PB 260, BPM1, PB 311 dan RRIC 100. Jarak tanam yang digunakan adalah 6 $\mathrm{m} \times 3.3 \mathrm{~m}$. Produksi dan produktivitas enam tahun terakhir dapat dilihat pada Tabel 1.

Tabel 1. Produksi dan produktivitas lateks di TGE 2007-2012

\begin{tabular}{clcc}
\hline Tahun & Luas $(\mathrm{ha})$ & Produksi $(\mathrm{kg})$ & Produktivitas $(\mathrm{kg})$ \\
\hline 2007 & 2517.5 & 2762117 & 1097.2 \\
2008 & 2490.7 & 1537570 & 617.3 \\
2009 & 2724.3 & 1304516 & 478.8 \\
2010 & 2477.8 & 835209 & 337.1 \\
2011 & 1557.3 & 324180 & 208.2 \\
2012 & 1375.3 & 246803 & 179.5 \\
\hline
\end{tabular}

${ }^{a}$ Sumber : EST-830A - Estate Monitoring Matrix - Crop TGE.

Tabel 1 memperlihatkan bahwa rata-rata produksi dan produktivitas di TGE sejak tahun 2008 terus-menerus mengalami penurunan drastis dengan produktivitas yang rendah, hal ini disebabkan adanya pencurian berupa penyadapan liar, sehingga terdapat pohon karet yang disadap dua kali dalam satu hari. Areal pohon karet yang teridentifikasi tersadap oleh penyadap liar hampir ditemui disetiap tanaman menghasilkan (TM) pada setiap divisi. Penyadapan liar yang tidak sesuai aturan juga menyebabkan banyak tanaman yang rusak, patah dan tumbang, serta tidak produktif lagi. Penurunan produksi juga disebabkan kepemilikan kebun plasma yang sebelumnya dikelola perusahaan seluas 909.70 ha, pada tahun 2010 dikembalikan ke masyarakat, sehingga ikut mempengaruhi dalam penurunan produksi.

Tabel 2. Persentase pohon yang dapat disadap per hanca sadap

\section{Persentase Pohon yang dapat Disadap}

Persentase pohon sadap merupakan persentase pohon yang telah memenuhi persyaratan untuk disadap atau persentase pohon yang dapat disadap per hanca sadap dari masingmasing penyadap. Sistem hanca yang digunakan di TGE adalah sistem hanca tetap. Sistem hanca tetap berarti masing-masing penyadap menyadap hanca yang sama dalam interval sesuai rotasi sadap yang digunakan, yaitu tiga hari $(1 / 2 \mathrm{~S} \mathrm{~d} / 3)$. Pembagian hanca masing-masing penyadap pun berbeda dan bervariasi. Jarak tanam yang digunakan di TGE adalah $6 \mathrm{~m}$ x $3.3 \mathrm{~m}$, sehingga populasi tanaman per hektar mencapai 505 tanaman. Rata-rata persentase pohon yang dapat disadap per hanca sadap dapat dilihat pada Tabel 2.

\begin{tabular}{|c|c|c|c|c|c|}
\hline \multirow[b]{2}{*}{$\begin{array}{l}\text { Nama } \\
\text { Penyadap }\end{array}$} & \multirow[b]{2}{*}{$\begin{array}{l}\text { Tahun } \\
\text { Tanam }\end{array}$} & \multirow{2}{*}{$\begin{array}{c}\text { Jumlah } \\
\text { Hanca } \\
\text { Diamati }\end{array}$} & \multicolumn{2}{|c|}{ Jumlah Pohon } & \multirow{2}{*}{$\begin{array}{c}\text { Persentase Pohon } \\
\text { Tersadap (\%) }\end{array}$} \\
\hline & & & Pohon/hanca & Pohon disadap & \\
\hline Amani & 2006 & 3 & 500 & 430 & 86.0 \\
\hline Budiono & 2006 & 3 & 499 & 428 & 85.7 \\
\hline Pendi & 2006 & 3 & 547 & 441 & 80.6 \\
\hline Wahyudi & 2006 & 3 & 488 & 414 & 84.8 \\
\hline Isbandi & 2004 & 3 & 501 & 443 & 88.4 \\
\hline Jumadi & 2004 & 3 & 550 & 501 & 88.6 \\
\hline Muslim & 2004 & 3 & 550 & 508 & 91.0 \\
\hline Rohadi & 2004 & 3 & 460 & 433 & 94.1 \\
\hline Rata-rata & & 3 & 511 & 449 & 87.4 \\
\hline
\end{tabular}


Tabel 2 memperlihatkan bahwa rata-rata populasi pohon/hanca adalah sebesar 511, sedangkan rata-rata persentase pohon yang dapat disadap per hanca sadap adalah sebesar $89.1 \%$ atau 449 pohon/hanca dari total populasi. Persentase pohon yang tersadap per hanca sadap di TGE masih tergolong wajar selama tidak dibawah dari $80 \%$, namun persentase pohon yang tersadap per hanca sadap di TGE lebih rendah jika dibandingkandi Kebun Sumber Tengah, PTPN XII. Menurut Ismail (2012) persentase pohon yang tersadap di Kebun Sumber Tengah, PTPN XII sebesar $90.98 \%$ dari total populasi.

Persentase pohon yang tersadap per hanca sadap di TGE hanya sebesar $87.4 \%$, hal ini dikarenakan terdapat banyak tanaman yang belum memenuhi kriteria matang sadap terutama pada tanaman tahun tanam 2006, sedangkan pada tahun tanam 2004 dikarenakan banyak tanaman yang terserang KAS, mati, dan tumbang akibat intensitas penyadapan yang terlalu sering terutama penyadapan yang dilakukan oleh penyadap liar pada malam hari.

\section{Persentase Pohon yang Terserang Kering Alur Sadap (KAS)}

Beberapa pohon yang tidak disadap oleh penyadap di Perkebunan TGE disebabkan terdapat beberapa pohon yang terserang kekeringan alur sadap (KAS). Kejadian pohon yang terserang KAS di TGE dapat dilihat pada Tabel 3.

Tabel 3. Tingkat serangan kekeringan alur sadap (KAS) pada dua tahun tanam

\begin{tabular}{ccc}
\hline Tahun Tanam & $\begin{array}{c}\text { NHanca yang } \\
\text { Diamati }\end{array}$ & $\begin{array}{l}\text { \%KAS (Kering alur } \\
\text { sadap) }\end{array}$ \\
\hline 2004 & 12 & $5.62 \mathrm{a}$ \\
2006 & 12 & $0.43 \mathrm{~b}$ \\
\hline
\end{tabular}

${ }^{a}$ Angka-angka yang diikuti oleh huruf berbeda pada kolom yang sama berbeda nyata pada uji $t$-student taraf $5 \%$.

Tabel 3 memperlihatkan bahwa persentase kejadian kekeringan alur sadap (KAS) pada tahun tanam 2004 lebih tinggi dibandingkan pada tahun tanam 2006. Hal ini mengindikasikan bahwa tanaman yang berumur lebih tua sering ditemui mengalami KAS lebih tinggi dikarenakan adanya interaksi dengan tingkat eksploitasi yang lebih tinggi. Menurut Sumarmadji (2001) bahwa tanaman yang berumur lebih tua sering dilaporkan mengalami kekeringan alur sadap (KAS) lebih tinggi dikarenakan adanya interaksi dengan tingkat eksploitasi yang lebih tinggi.

Pohon yang terserang kering alur sadap (KAS) di TGE bukan diindikasikan karena tanaman tersebut telah berumur lebih tua, tetapi lebih disebabkan karena adanya intensitas penyadapan yang terlalu sering, terutama adanya penyadapan liar yang dilakukan pada malam hari terutama pada tahun tanam 2004, sehingga dalam satu hari tanaman karet disadap dua kali, ditambah masih diaplikasikan penggunaan stimulansia atau ethrel.

Pohon yang terserang kering alur sadap (KAS) pada tahun tanam 2004 di TGE sebesar $5.62 \%$ dari populasi. Namun kejadian kering alur sadap (KAS) pada tahun tanam 2004 di TGE masih tergolong dalam batas yang dapat ditolerir diabndingkan kejadian KAS di PTP Nusantara lainnya. Sumarmadji (2001) menyatakan bahwa secara umum kejadian KAS yang terjadi di PTP Nusantara berkisar $6-25 \%$ terhadap populasi menghasilkan.

Penyakit brown blast atau kekeringan alur sadap (KAS) bukan disebabkan oleh infeksi mikroorganisme, melainkan karena penyadapan yang terlalu sering, terlebih jika disertai penggunaaan bahan perangsang lateks (Damanik et al. 2010). Menurut Anwar (2001) kekeringan alur sadap (KAS) mengakibatkan pohon yang disadap tidak mengalirkan lateks dari sebagian alur sadap. Kemudian dalam beberapa minggu kemudian seluruh alur sadap menjadi kering dan tidak mengeluarkan lateks, bagian yang kering berubah warna menjadi cokelat, kulit menjadi pecah-pecah dan di batang terjadi pembengkakan atau tonjolan. Jika persentase pohon yang terserang penyakit Bown blast atau kekeringan alur sadap (KAS) dalam jumlah yang banyak tentu akan sangat berpengaruh terhadap produksi dan produktivitas yang dihasilkan.

Beberapa upaya pengendalian yang bisa dilakukan, antara lain dengan mengistirahatkan pohon karet yang terserang kering alur sadap (KAS) sampai pohon karet tersebut dapat mengeluarkan lateks kembali. Selanjutnya tidak melakukan penyadapan yang terlalu sering dan dianjurkan mengurangi

\section{Kondisi Kulit Sadapan}

Konsumsi kulit dan kedalaman sadapan sangat menentukan umur produksi tanaman, sehingga diperlukan teknik penyadapan yang sesuai dengan aturan-aturan yang telah ditetapkan oleh perusahaan. Konsumsi kulit anjuran TGE adalah $1.7 \mathrm{~mm}$ per hari sadap untuk sistem sadap $1 / 2 \mathrm{~S} \mathrm{~d} / 3$, sehingga konsumsi kulit anjuran per bulan adalah $17 \mathrm{~cm}$. Hasil pengamatan kondisi kulit sadapan di TGE dapat dilihat pada Tabel 4. 
Tabel 4. Kondisi kulit sadapan beberapa penyadap di TGE pada tanaman menghasilkan (TM) tahun tanam 2006

\begin{tabular}{cccccc}
\hline Penyadap & $\begin{array}{c}\text { Lilit Batang } \\
(\mathrm{cm})\end{array}$ & $\begin{array}{c}\text { Tinggi } \\
\text { Alur Sadap } \\
(\mathrm{cm})\end{array}$ & $\begin{array}{c}\text { Panjang } \\
\text { Alur Sadapan } \\
(\mathrm{cm})\end{array}$ & $\begin{array}{c}\text { Konsumsi } \\
\text { Kulit Sadapan } \\
(\mathrm{mm})\end{array}$ & $\begin{array}{c}\text { Kedalaman } \\
\text { Irisan Sadapan } \\
\text { dari Kambium } \\
(\mathrm{mm})\end{array}$ \\
\hline 1 & 54.57 & 101.48 & 30.43 & 1.42 & 1.59 \\
2 & 55.14 & 103.09 & 31.41 & 1.98 & 1.87 \\
3 & 53.38 & 103.10 & 31.16 & 1.66 & 1.40 \\
4 & 55.19 & 102.40 & 31.01 & 2.02 & 1.62 \\
\hline Rata-rata & 54.57 & 102.51 & 31.00 & 1.77 & 1.62 \\
\hline
\end{tabular}

Tabel 4 memperlihatkan bahwa konsumsi kulit sadapan di lapangan sedikit melebihi konsumsi kulit yang dianjurkan perusahaan, yakni $1.77 \mathrm{~mm}$, sedangkan konsumsi kulit sadapan anjuran perusahaan adalah $1.70 \mathrm{~mm}$. Namun konsumsi kulit di lapangan masih tergolong wajar dan masih dapat ditolerir selama tidak melebihi dari $2 \mathrm{~mm}$. Menurut Siregar dan Suhendry (2013) ketebalan irisan kulit saat penyadapan sebaiknya tidak terlalu tebal yakni $1.5-2 \mathrm{~mm}$, karena jika terlalu tebal akan menyebabkan pemborosan kulit dan mempercepat habisnya kulit bidang sadapan sehingga umur produksi lebih pendek dan singkat dari seharusnya .

Tabel 4 juga menunjukkan bahwa kedalaman irisan sadapan di TGE masih kurang dalam dan masih bisa diekploitasi sampai batasan kedalaman irisan sadapan anjuran perusahaan, yakni 1-1.5 mm dari lapisan kambium. Menurut Damanik et al. (2010) penyadapan yang terlalu dangkal akan menyebabkan berkas pembuluh lateks yang terpotong sedikit. Jumlah berkas pembuluh lateks yang terpotong akan mempengaruhi jumlah lateks yang keluar. Semakin sedikit berkas pembuluh lateks yang terpotong maka semakin sedikit jumlah lateks yang keluar, tetapi penyadapan yang terlalu dalam sampai melukai kambium akan mengakibatkan kulit pulihan rusak atau tidak rata, sehingga akan menyulitkan dalam penyadapan berikutnya.

Tinggi alur sadap yang diukur saat ini dipengaruhi oleh ketebalan kulit yang disadap. Semakin tipis penyadapan maka pemakaian kulit semakin hemat, begitu juga sebaliknya semakin tebal irisan sadap maka pemakaian kulit akan semakin boros, panjang alur sadapan tergantung dari besar tanaman atau lilit batang tanaman. Semakin besar atau semakin panjang lilit batang nya maka semakin panjang alur sadapnya .

Rata-rata lilit batang dari hasil pengamatan adalah $54.57 \mathrm{~cm}$, hal ini menunjukkan bahwa tanaman karet tersebut telah memenuhi kriteria matang sadap, dimana lilit batangnya $>45 \mathrm{~cm}$ sesuai dengan umur tanaman yang telah memasuki umur 7 tahun. Menurut
Setiawan dan Andoko (2008) kriteria dalam menentukan matang sadap karet adalah dengan melihat umurnya. Biasanya karet telah matang sadap setelah berumur lima tahun, dengan catatan tanaman berada pada lingkungan yang sesuai dan pertumbuhannya normal. Kriteria lain untuk menentukan matang sadap karet adalah dengan melihat ukuran lilit batang. Lilit batang dinilai bisa memberi informasi ketebalan kulit dan kemampuan fisiologis menghasilkan lateks dalam jangka waktu lama. Jika 65\% dari sampel pohon telah memiliki lilit batang $45 \mathrm{~cm}$ yang diukur pada jarak $130 \mathrm{~cm}$ dari permukaan tanah, berarti di areal tersebut sudah bisa dilakukan penyadapan.

Tinggi bukaan alur sadap di TGE adalah $150 \mathrm{~cm}$ dari permukaan tanah. Rata-rata tinggi alur sadap hasil pengamatan adalah $102.51 \mathrm{~cm}$, hal ini menunjukkan bahwa tingkat konsumsi kulit dalam kurun waktu dua tahun sebesar 47.49 $\mathrm{cm}$. Tingkat konsumsi kulit tersebut masih tergolong boros, seharusnya berdasarkan standar konsumsi kulit perusahaan dalam kurun waktu 2 tahun konsumsi kulit yang terpakai sebesar $42 \mathrm{~cm}$. Hal ini berkorelasi dengan tingkat konsumsi kulit di lapangan yang sedikit melebihi dari standar perusahaan.

\section{Penggunaan Stimulansia}

Berdasarkan petunjuk perusahaan, aplikasi pemberian stimulansia untuk pohon yang lebih kecil sebanyak 2 tetes $(0.55 \mathrm{cc})$ dengan 0.25 cc stimulan/tetes, sedangkan untuk pohon yang lebih besar sebanyak 3 tetes atau $0.75 \mathrm{cc} /$ pohon. Selanjutnya sekrap pada alur sadap ditarik dengan menggunakan cungkit, kemudian meneteskan larutan stimulan dari botol mineral pada alur sadap 2-3 tetes lalu dioles sampai merata menggunakan kuas kecil atau sikat.

Hasil pengamatan langsung dan wawancara dengan mandor - mandor di lapangan proses pengenceran stimulansia (ethrel) sudah sesuai rekomendasi perusahaan dengan perbandingan 1: 3, yakni 1 liter ethrel dan 3 liter air (aquades). Namun pelaksanaan aplikasi di 
lapangan menunjukkan bahwa para pekerja memberikan larutan stimulansia sering kali melebihi dosis yang dianjurkan perusahaan atau tidak sesuai dengan standar, setiap tetesnya lebih dari $0.25 \mathrm{cc}$ stimulan atau pemberian yang lebih dari 3 tetes, kemudian untuk aplikasi sadap bawah setelah ditetesi ethrel pada alur sadap tidak olesi dengan kuas secara merata, hal ini menyebabkan pemberian ethrel yang tidak merata pada alur, serta tidak adanya pengawasan secara langsung dari mandor, sehingga pemberian stimulansia oleh para pekerja sering melebihi dosis yang dianjurkan perusahaan. Oleh karena itu, perlu adanya pengawasan secara langsung dari mandor di lapangan, agar para pekerja bekerja sesuai dengan prosedur yang telah ditetapkan perusahaan.

Aplikasi stimulansia yang berlebihan akan menimbulkan kerugian karena akan berdampak pada terjadinya penyakit kering alur sadap (KAS). Menurut Siregar dan Suhendry (2013) salah satu penyebab penyakit bidang sadap kering alur sadap (KAS) adalah penggunaan stimulansia yang berlebihan, dengan menggunakan stimulansia maka potensi KAS menjadi tinggi. Bila angka KAS (parsial maupun total) sudah $>8 \%$ dari suatu populasi maka penggunaan stimulansia segera dihentikan

Penggunaan stimulansia pada umumnya akan menurunkan kadar karet kering (KKK). Namun selama penurunan itu tidak lebih dari 3\%, maka penggunaan stimulansia dapat diteruskan. Namun bila penurunan kadar karet kering (KKK) lateks sudah > 3\% maka langkah yang harus dilakukan adalah menghentikan penggunaan stimulansia (Siregar dan Suhendry 2013).

\section{Tenaga Kerja Sadap Terhadap Produksi Lateks}

Analisis tenaga kerja sadap terhadap produksi lateks di TGE meliputi : usia, pendidikan, dan pengalaman menyadap, sehingga perlu dilakukan pengamatan dan wawancara terhadap tenaga penyadap untuk membandingkan produksi lateks yang dihasilkan penyadap yang bebeda usia, pengalaman, dan pendidikan. Pengamatan terhadap produksi lateks yang dihasilkan berdasarkan usia penyadap, yaitu dengan membandingkan usia penyadap $<33$ tahun dan usia penyadap $\geq 33$ tahun. Data pengamatan terhadap produksi yang dihasilkan berdasarkan usia dapat dilihat pada Tabel 5 .

Tabel 5 Perbandingan produksi yang dihasilkan penyadap yang berbeda usia

\begin{tabular}{clcc}
\hline Tingkat Usia & $\begin{array}{c}\text { Nama } \\
\text { Penyadap }\end{array}$ & $\begin{array}{c}\text { Usia } \\
\text { (tahun) }\end{array}$ & $\begin{array}{c}\text { Rata- rata } \\
\text { Produksi Lateks } \\
\text { (kg/hari) }\end{array}$ \\
& Joni S & 32 & 51.2 \\
& Ahmad R & 27 & 49.1 \\
Usia $<33$ tahun & 20 & 51.8 \\
& Wahyudin & 26 & 48.7 \\
& Yulianto & 28 & 46.8 \\
\hline Rata-rata & Nuryanto & 26.6 & $49.52 \mathrm{a}$ \\
\hline & & 33 & 50.0 \\
& Bejo & 33 & 50.4 \\
& Musliadi & 35 & 44.6 \\
& Senen & 34 & 48.1 \\
& Misto & 35 & 46.4 \\
\hline Ratahun tata & Sarul & 34 & $47.90 \mathrm{a}$ \\
\hline Koefisien Keragaman $(\mathrm{KK})$ & & & $4.57 \%$ \\
\hline
\end{tabular}

Keterangan: a Angka-angka yang diikuti huruf yang sama pada kolom yang sama menunjukkan hasil yang tidak berbeda nyata pada uji $t$ - student taraf $5 \%$.

Tabel 5 menunjukkan bahwa penyadap yang berusia $<33$ tahun menghasilkan produksi lebih tinggi dari pada penyadap yang berusia $\geq 33$ tahun. Namun hasil uji t- student pada taraf 5\% tidak menunjukkan perbedaan yang nyata artinya usia penyadap tidak mempengaruhi terhadap produksi yang dihasilkan.

Selanjutnya pengamatan dilakukan dengan membandingkan produksi lateks yang dihasilkan oleh penyadap yang mempunyai dua tingkat pengalaman yang berbeda, yakni penyadap (tapper) yang memiliki pengalaman $<6$ tahun dan penyadap yang memiliki pengalaman $\geq$ 6 tahun. Data hasil pengamatan terhadap produksi yang dihasilkan penyadap dengan tingkat pengalaman yang berbeda dapat dilihat pada Tabel 6. 
Tabel 6. Perbandingan produksi yang dihasilkan penyadap yang berbeda pengalaman

\begin{tabular}{clcc}
\hline $\begin{array}{c}\text { Tingkat } \\
\text { Pengalaman }\end{array}$ & $\begin{array}{c}\text { Nama } \\
\text { Penyadap }\end{array}$ & $\begin{array}{c}\text { Pengalaman } \\
\text { Menyadap } \\
\text { (tahun) }\end{array}$ & $\begin{array}{c}\text { Rata- rata } \\
\text { Produksi Lateks } \\
\text { (kg/hari) }\end{array}$ \\
\hline Pengalaman & Joni S & 5 & 51.1 \\
$<6$ tahun & Ahmad R & 4 & 49.0 \\
& Musliadi & 5 & 50.4 \\
Yulianto & Nuryanto & 3 & 48.7 \\
\hline Rata-rata & & 5 & 46.8 \\
\hline Pengalaman & Bejo & 4.4 & $49.2 \mathrm{a}$ \\
\hline A tahun & Wahyudin & 7 & 50.0 \\
& Misto & 9 & 51.1 \\
\hline Rata-rata & Sarul & 11 & 51.8 \\
\hline Koefisien Keragaman & & 48.1 \\
\hline angka-angka yang diikuti oleh huruf sama pada kolom yang sama tidak berbeda nyata pada uji $t$ - student taraf 5\%.
\end{tabular}

Tabel 6 menunjukkan bahwa pengalaman penyadap tidak mempengaruhi terhadap produksi lateks yang dihasilkan oleh penyadap. Menurut Asim (2012) pengalaman penyadap juga tidak selalu mempengaruhi terhadap produksi lateks yang dihasilkan oleh penyadap di PT Air Muring, Bengkulu.

Pengamatan juga dilakukan terhadap kelas sadap dengan membandingkan produksi yang dihasilkan oleh penyadap yang berpendidikan SD dengan penyadap yang berpendidikan SMP. Data pengamatan terhadap produksi yang dihasilkan antara penyadap berpendidikan SD dan penyadap berpendidikan SMP dapat dilihat pada Tabel 7.

Tabel 7. Perbandingan produksi yang dihasilkan penyadap yang berbeda pendidikan

\begin{tabular}{|c|c|c|}
\hline Tingkat & ¿Tenaga & Produksi \\
\hline Pendidikan & Penyadap & $\begin{array}{l}\text { Lateks } \\
\text { (kg/hari) }\end{array}$ \\
\hline SD & 3 & $50.20 \mathrm{a}$ \\
\hline SMP & 3 & $50.25 \mathrm{a}$ \\
\hline Keterangan: & $\begin{array}{l}\text { gka yang di } \\
\text { n yang sama } \\
\text { student tara }\end{array}$ & $\begin{array}{l}\text { h huruf sama } \\
\text { erbeda nyata }\end{array}$ \\
\hline
\end{tabular}

Tabel 7 memperlihatkan bahwa produksi lateks yang dihasilkan oleh penyadap yang berpendidikan SD dan SMP tidak mempengaruhi terhadap produksi yang dihasilkan. Faktor pendidikan juga tidak mempengaruhi terhadap hasil lateks yang dihasilkan penyadap di PT Air Muring, Bengkulu (Asim 2012). Hal ini menunjukkan bahwa faktor pendidikan tidak mempengaruhi terhadap produksi lateks yang dihasilkan oleh penyadap.
Analisis tenaga kerja sadap terhadap produksi yang dihasilkan penyadap, menunjukkan bahwa faktor usia, pengalaman dan pendidikan tidak mempengaruhi terhadap produksi lateks yang dihasilkan oleh penyadap di TGE.

\section{KESIMPULAN}

Kegiatan penelitian yang dilakukan di TGE dapat meningkatkan pengetahuan dan pengalaman dalam mempelajari sistem penyadapan tanaman karet baik melalui kegiatan teknis maupun manajerial. Kegiatan penyadapan di TGE adalah salah satu kegiatan yang diutamakan karena merupakan kegiatan utama perusahaan untuk mencapai target produksi. Manajemen yang baik dan terkontrol akan menjamin keberlanjutan umur produksi dan umur ekonomis tanaman secara terus menerus. Namun sistem penyadapan di TGE yang menyangkut persentase pohon yang dapat disadap, kedalaman irisan sadapan, konsumsi kulit, kering alur sadap (KAS), dan penggunaan stimulansia masih memerlukan perhatian.

Rata-rata persentase pohon yang dapat disadap per hanca sadap di Perkebunan TGE adalah sebesar $87.4 \%$ atau 449 pohon/hanca dari total populasi. Persentase pohon yang terserang kering alur sadap (KAS) pada tahun tanam 2004 di TGE lebih tinggi yaitu sebesar 5.62\%, sedangkan persentase tanaman yang terserang kering alur sadap (KAS) pada tahun tanam 2006 yaitu sebesar $0.43 \%$. Rata-rata konsumsi kulit sadapan di TGE sedikit melebihi dari standar perusahaan yakni lebih dari $1.70 \mathrm{~mm}$, sedangkan rata-rata konsumsi kulit sadapan di lapangan adalah $1.77 \mathrm{~mm}$, hal ini masih tergolong wajar dan masih dapat ditolerir. Kedalaman sadapan di 
TGE adalah $1.62 \mathrm{~mm}$ dari lapisan kambium dan masih kurang dalam, sesuai dengan kedalaman sadapan anjuran perusahaan yaitu seharusnya 1-1. $5 \mathrm{~mm}$ dari lapisan kambium.

Aplikasi stimulansia di lapangan menunjukkan bahwa para pekerja memberikan larutan stimulansia sering kali melebihi dosis yang dianjurkan perusahaan. Aplikasi pada sadap bawah tidak diolesi dengan kuas serta tidak adanya pengawasan secara langsung dari mandor di lapangan. Faktor usia, pengalaman, dan pendidikan tenaga kerja penyadap di TGE, tidak mempengaruhi tingkat produksi yang dihasilkan oleh penyadap.

\section{DAFTAR PUSTAKA}

Anwar C. 2001. Manajemen dan Teknologi Budidaya Karet. Medan (ID): Pusat Penelitian Karet.

Asim M. 2012. Penyadapan kiaret (Hevea brasiliensis Muell Arg.) di PT Air Muring, Bengkulu. [skripsi]. Bogor (ID): Institut Pertanian Bogor.

Boerhendhy I, Amypalupy K. 2010. Optimalisasi produktivitas karet melalui penggunaan bahan tanam, pemeliharaan, sistem eksploitasi, dan peremajaan tanaman [Internet]. [diunduh 12 Januari 2013]. Tersedia pada http//www.pustaka.litbang.deptan.go.id.
[BPS] Badan Pusat Statistik. 2012. Statistik Karet Indonesia 2011 [Internet]. [diunduh 15 Desember 2012]. Tersedia pada : http://www.bps.go.id.

Damanik S, Syakir M, Tasma M, Siswanto. 2010. Budidaya dan Pasca Panen Karet. Pusat Penelitian dan Pengembangan Perkebunan. Bogor (ID): Eska Media.

Ismail M. 2012. Penyadapan tanaman karet (Hevea brasiliensis Muell Arg.) di Kebun Sumber Tengah PT Perkebunan Nusantara X11, Jember, Jawa Timur [skripsi]. Bogor (ID): Institut Pertanian Bogor. .

Setiawan DH, Andoko A. 2008. Petunjuk Lengkap Budi Daya Karet. Jakarta (ID): PT Agromedia Pustaka.

Siregar THS, Suhendry I. 2013. Budidaya dan Teknologi Karet. Jakarta (ID): Penebar Swadaya.

Sumarmadji. 2001. Pengendalian kering alur sadap dan nekrosis pada kulit tanaman karet. Warta Pusat Penelitian karet. 20 (1-3): 76-78.

Walpole RE. 1992. Pengantar Statistika. Edisi ke - 3. Jakarta (ID): PT Gramedia Pustaka 